\title{
Kebiasaan Mengkonsumsi Alkohol pada Remaja Siswa SMA Negeri 3 Sorong
}

\author{
Irma idris ${ }^{, *}$, Arman $^{2}$, Afriyanti Gobel ${ }^{3}$ \\ 1*. STIKES Papua, Jl. Kanal Victory Km.10, Kota Sorong, Indonesia, 98416 \\ 2. Universitas Muslim Indonesia, J1. Urip Sumoharjo KM.5, Kota Makassar, Indonesia, 90231 \\ 3. Universitas Muslim Indonesia, J1. Urip Sumoharjo KM.5, Kota Makassar, Indonesia, 90231 \\ e-mail: irmaidris402@gmail.com
}

(Received : 24-07-2019; Reviewed : 21-08-2019; Accepted : 26-08-2019)

\begin{abstract}
The purpose of this research was to determine the factors that encourage the habit of consuming alcohol in adolescent students in Sorong Papua High School 3. This research is an observational study that uses a qualitative approach with a phenomenological design by using in-depth interview instruments. The technique of taking informants in this study is purposive sampling, which is the method of selecting participants based on the principle of appropriateness and the principle of adequacy. The selection of informants based on the principle of conformity is informants who have knowledge related to the research topic. The results showed that the informant's personality towards alcohol consumption is a predisposing factor that encourages adolescent habits to consume alcohol, especially in the school area. The role of the school, peers, the local community, and the local government is a reinforcing factor and enabling factor that encourages the consumption of alcohol in adolescents and can become an important role in answering the habits of alcohol consumption in adolescents, so that the availability of access to getting an alcoholic around the school environment it is seen several stalls around the school freely sell alcohol without pocketing a license as a sales agent. The number of informants in this study amounted to 29 informants from 6 students, 6 parents, 1 principal, 2 teachers, 5 peers, 1 person from the local government apparatus and 1 person from the SAT Narcotics Police, 2 people from community leaders, 5 people selling alcoholic beverages.
\end{abstract}

Keywords: Alcohol Consumption, Behavior, Students

\begin{abstract}
Abstrak
Tujuan penelitian ini adalah untuk mengetahui faktor yang mendorong kebiasaan mengkonsumsi alkohol pada remaja siswa di sekolah SMA N 3 Sorong Papua. Penelitian ini merupakan jenis penelitian observasional yang menggunakan pendekatan kualitatif dengan rancangan fenomenologi. Dengan menggunakan instrumen wawancara mendalam (indepth interview). Teknik pengambilan informan pada penelitian ini adalah purposive sampling yaitu metode pemilihan partisipan berdasarkan asas kesesuaian (appropriatness) dan asas kecukupan (adequacy). Pemilihan informan berdasarkan asas kesesuaian adalah informan yang memiliki pengetahuan yang berkaitan dengan topik penelitian. Hasil Penelitian menunjukkan bahwa, kepribadian informan terhadap konsumsi alkohol termasuk faktor predisposisi yang mendorong kebiasaan remaja mengkonsumsi alkohol terutama di area sekolah. Peran Sekolah, peran teman sebaya, masyarakat setempat, dan pemerintah daerah menjadi faktir pendorog terhadap kebiasaan mengkonsumsi alkohol pada remaja, pun bias menjadi peran penting dalam melawab kebiasaan konsumsi alkohol pada remaja, ketersediaan akses dalam mendapatkab alkohol di sekitar lingkungan sekolah menjadi faktor yang sangat mendukung siswa mudah mendapatkan alkohol, dilihat beberapa warung-warung disekitar sekolah dengan bebas menjual alkohol, tanpa mengantongi surat izin sebagai agen penjual. Jumlah Informan dalam penelitian ini berjumlah 29 informan yaitu 6 siswa sekolah SMAN 3 Sorong, 6 orang tua siswa, 1 Kepala Sekolah, 2 orang guru, 5 orang teman sebaya, 1 org dari aparatur pemerintah daerah (Badan Hukum Pengawasan dan Pengendalian Minuman Beralkohol) dan 1 orang dari Kepolisian SAT Narkoba, 2 orang dari tokoh masyarakat, 5 orang penjual minuman alkohol.
\end{abstract}

Kata Kunci: Konsumsi Alkohol, Perilaku, Remaja 


\section{Pendahuluan}

Remaja sebagai individu sedang berada dalam proses berkembang atau menjadi (becoming), yaitu berkembang kearah kematangan atau kemandirian. Untuk mencapai kematangan tersebut, remaja memerlukan bimbingan karena mereka masih kurang memiliki pemahaman atau wawasan tentang dirinya dan lingkungannya, juga pengalaman dalam menentukan arah kehidupannya. Proses perkembangan individu tidak selalu berjalan secara mulus atau sesuai harapan dan nilai-nilai yang dianut, karena banyak faktor yang menghambatnya. Faktor penghambat ini bisa bersifat internal atau eksternal. Faktor eksternal adalah yang berasal dari lingkungan seperti ketidak stabilan dalam kehidupan sosial politik, krisis ekonomi, perceraian orang tua, sikap dan perlakuan orang tua yang otoriter atau kurang memberikan kasih sayang dan pelecehan nilai-nilai moral atau agama dalam kehidupan agama atau masyarakat. Pada saat sekarang banyak remaja yang mengatakan bahwa dengan minum-minuman keras kepercayaan diri mereka bertambah dari yang pemalu menjadi pemberani, mereka beranggapan bahwa semua masalah dapat teratasi dengan minum-minuman keras, minuman keras dapat memperbanyak teman. Tetapi sesuai kenyataan minuman keras dapat merusak proses berfikir dan menjadikan orang tidak sadarkan diri atau bertindak tidak sesuai kehendak.

Hasil penelitian Cahya (2015) menunjukkan bahwa sosiologi hukum faktor penyebab remaja mengonsumsi minuman beralkohol adalah tidak efektifnya penerapan dari PERDA Pengawasan dan Pengendalian Pengadaan, Peredaran dan Penjualan Minuman Beralkohol. Khususnya pada pasal 6 yanG mengatur bahwa hanya yang berusia 21 tahun keatas yang dapat membeli dan mengkonsumsi minuman beralkohol sehingga dengan mudahnya para remaja untuk memperoleh minuman beralkohol yang mudah di dapat di lapangan akan mempenagruhi keinginan reaja untuk mencoba menggunakan alkohol, dan ini juga disebabkan karena keterjangkauan bagi remaja yang membelinya. Sekaranf penjualan minuman keras yang semakin luas dn tidk terkontrol merupakan fenomena pada masyarakat., seperti misalnya pada mini market, café, warung remangremang, club, sampai warung kecil pun meyediakan minuman beralkohol atau minuman keras (Waluyo, 2014).

Minuman keras dan minuman alkohol sebagai media transisi dari perilaku negative ringan ke perilaku negative yang berat harus sedini mungkin di cegah penyebarluasannya terutama di kalangan remaja. Desakan untuk menggalang kampanye anti minuman keras dan anti minuman alkohol telah banyak di suarakan oleh berbagai kalangan masyarakat sebagai bentuk kepedulian dan perlawan terhadap barang haram tersebut. Desakan itu di lakukan karena menyadari betapa bahayanya miras dan minol bagi kesehatan manusia dan lingkungan (Putra, 2013)

Di Kota Sorong berdasarkan data dari hasil wawancara Ka.Reskrim (Residivis Kriminalis) sepanjang tahun 2017, kasus kriminal terdapat lebih dari 1000 kasus. 25\% kasus pemerkosaan, pencurian, pemukulan, dan perkelahian diakibatkan karena konsumsi alkohol, $15 \%$ diantaranya adalah anak remaja yang terlibat perkelahian dan pemukulan karena dampak dari konsumsi alkohol. Hal ini membuktikan bahwa perilaku konsumsi alkohol berdampak sangat buruk bagi lingkungan sekitar. Selain itu, penjualan minuman beralkohol yang liar tanpa mengantongi surat izin dari kepolisian, dan kurangnya pengawasan orang tua, menjadi hal pemicu semakin meningkatnya perilaku konsumsi alkohol pada remaja di kota sorong yang berakibat pada tindakan- tindakan kriminal.

Untuk membentengi remaja dari perilaku miras dan minol perlu adanya tindakan pencegahan dari elemen kunci yaitu dari sekolah, keluarga, masyarakat dan pemerintah. Sekolah sebagai lingkungan yang menjembatani tumbuh kembang remaja baik di bidang olahraga, kesenian, dan lain-lain. Untuk jangka panjang, disarankan agar Usaha Kesehatan Sekolah bagi remaja dikembangkan dan keterampilan guru bimbingan dan koselig di tingkatkan. Tujuan penelitian ini adalah untuk mengetahui faktor yang mendorong kebiasaan mengkonsumsi alkohol pada remaja siswa di sekolah SMA N 3 Sorong Papua.

\section{Metode}

Penelitian ini merupakan jenis penelitian observasional yang menggunakan pendekatan kualitatif dengan rancangan fenomenologi. Fenomenologi merupakan sebuah strategi penyelidikan dimana peneliti mengidentifikasi esensi dari pengalaman individu tentang suatu fenomena sebagaimana di ungkapkan oleh individu itu sendiri. Rancangan ini digunakan untuk mengeksplorasi kebiasaan konsumsi alkohol pada remaja siswa SMA N 3 Sorong secara sadar, juga terkait kepribadian, keluarga (orang tua), peran sekolah, teman sebaya, peran pemerintah setempat,tokoh masyarakat, serta ketersediaan akses dalam memperoleh alkohol.

Penelitian kualitatif yang menjadi instrumen atau alat penelitian adalah peneliti itu sendiri. Peneliti menggunakan instrumen wawancara mendalam (indepth interview) berupa panduan pertanyaan yang disusun sesuai dengan topik yang akan dibicarakan, telaah dokumentasi dan pengamatan secara langsung (observasi). Untuk memperjelas informasi yang akan diperoleh, peneliti juga menggunakan alat bantu berupa alat tulis dan alat rekam, kamera, pedoman wawancara dan pedoman observasi. Penelitian ini di lakukan di SMA N 3 Sorong Papua di mulai pada bulan agustus hingga oktober 2018. Peneliti tertarik melakukan peelitian di Sekolah tersebut karena SMA N 3 Sorong Papua adalah salah satu sekolah milik pemerintahan provinsi yang terkenal 
sebagai sekolah unggulan di Kota Sorong Papua, dengan peraturan dan standar yang ketat namun di temukan beberapa siswanya dengan perilaku konsumsi alkohol. Teknik pengambilan informan pada penelitian ini adalah purposive sampling yaitu metode pemilihan partisipan dalam suatu penelitian dengan menentukan terlebih dahulu kriteria yang akan dimasukkan dalam penelitian, pemilihan informan berdasarkan asas kesesuaian (appropriatness) dan asas kecukupan (adequacy). Pemilihan informan berdasarkan asas kesesuaian adalah informan yang memiliki pengetahuan yang berkaitan dengan topik penelitian. Pemilihan informan berdasarkan asas kecukupan adalah informan yang dapat menggambarkan seluruh fenomena yang berkaitan dengan topik penelitian.

Jumlah Informan dalam penelitian ini berjumlah 29 informan yaitu 6 siswa sekolah SMAN 3 Sorong, 6 orang tua siswa, 1 Kepala Sekolah, 2 orang guru, 5 orang teman sebaya, 1 org dari aparatur pemerintah daerah (Badan Hukum Pengawasan dan Pengendalian Minuman Beralkohol) dan 1 orang dari Kepolisian SAT Narkoba, 2 orang dari tokoh masyarakat, 5 orang penjual minuman alkohol.

Analisis data dalam penelitian ini dilakukan pada saat pengumpulan data berlangsung dan setelah selesai pengumpulan data dalam periode tertentu. Analisis data dengan content analysis yaitu mengidentifikasi berbagai karakteristik khusus suatu pesan secara objektif, sistematis, dan generalis untuk mengambil suatu kesimpulan.

\section{Hasil}

Karakteristik demografi informan siswa dengan kebiasaan mengkonsumsi alkohol berusia 15-18 tahun yang menempuh pendidikan formal di SMAN 3 Sorong yang diketahui pernah mengkonsumsi alkohol, informan pihak sekolah adalah seseorang yang memiliki kebijakan didalam sekolah yaitu kepala sekolah, dan seseorang yang diberi amanah sebagai pihak yang memberikan bimbingan terhadap kebiasaan menyimpang remaja, informan pihak pemerintah adalah seseorang yang berpengaruh dan menjadi konsultan terkait PERDA pengawas dan pengendalian minuman keras, informan aparat (kepolisian) adalah polisi yang bertugas di SAtgas Narkoba dan Reskrim Kapolres Sorong Papua, Agen/Distributor alkohol baik itu diwarung atau individu yang menjual alkohol secara pribadi.

Hasil Penelitian ini menunjukkan bahwa, kebiasaan mengkonsumsi alkohol pada remaja siswa SMA N 3 Sorong Papua, dan faktor-faktor yang membentuk kebiasaan tersebut telah di ketahui alasan-alasan dan penyebab kebiasaan konsumsi alkohol para remaja di sekolah, bagaimana kepribadian remaja di sekolah terhadap kebiasan konsumsi alkohol, bagaimana dampak mengkonsumsi alkohol, bagaimana keluarga, lingkungan sekolah, teman sebaya, tokoh masyarakat setempat, pemerintah daerah, dan ketersediaan akses terhadap kebiasaan mengkonsumsi alkohol pada remaja siswa di sekolah. Semua faktor saling berhubungan dan saling terikat satu sama lain.

1. Dari Hasil wawancara dapat disimpulkan bahwa Kepribadian pengguna alcohol turut berperan terhadap remaja. Penyalahgunaan alkohol memiliki konsep diri dan harga diri yang rendah. Perkembangan emosi yang terhambat dengan ditandai ketidakmampuan individu mengekspresikan emosinya secara wajar, mudah cemas, pasif, agresif dan cenderung depresi. Hal ini turut mempengaruhi konsumsi alkohol pada remaja.

2. Seluruh informan memiliki hubungan yang baik dengan orang tuanya, karena semua informan tinggal bersama anaknya. Namun kenyataannya walaupun mereka memiliki hubungan yang baik, ada saat di mana komunikasi di antara mereka menjadi tidak harmonis, sehingga orang tua sering melakukan kekerasan fisik kepada anaknya, dan untuk menghilangkan kekecewaan atas sikap orang tua pada mereka, tidak sedikit remaja kemudian melakukan penyimpangan dengan mengkonsumsi minuman beralkohol. konsumsi minuman beralkohol pada remaja adalah bahwa anak-anak muda yang berasal dari rumah tangga yang hubungannya tidak harmonis, dimana orang tua tidak terlalu memperhatikan pergaulan anak-anaknya dan senang memberikan hukuman fisk yang keras, lebih mudah untuk menjadi anak yang berperilku menyimpang dibandingkan anak-anak muda yang berasal dari lingkungan yang harmonis

3. Sekolah sudah melakukan peranannya dengan sangat baik, terkait upaya melawan penayalahgunaan alkohol. Namun pada kenyataannya masih banyak para siswa nya, menyalahgunakan alkohol, masih ada saja beberapa siswa yang dengan sembunyi-sembunyi membawa alkohol kedalam lingkungan sekolah. UNtuk itu sekolah memiliki tata tertib terkait pelanggaran yang telah dilakukan dengan mengeluarkan siswa tersebut dari sekolah untuk memberikan efek jera dan peringatan bagi siswa yang lain ketika melakukan tindakan yang merugikan diri nya sendiri termasuk menyalahgunakan alkohol di dalam lingkungan sekolah.

4. Bahwa sebagian diantara siswa dipengaruhi oleh teman main yang sebaya, dan pernah mengkonsumsi Alkohol bersama sama dengan teman sebayanya di sekolah, bahkan ada yang pertama kali mengkonsumsi alkohol di lingkungan tempat tnggal mereka. Dalam lingkungan sekolah terdapat interaksi teman sebaya dimana proses interaksi teman sebaya akan saling mempengaruhi, karena adanya penyesuaian diri pada norma/aturan/nilai-nilai yang sudah ditetapkan dalam interaksi teman sebaya. Menurut Jaji (2009) resiko penyalahgunaan NAPZA pada umunya pertama kali dikenalkan oleh teman. Perilaku menyalahgunakan NAPZA pada remaja juga merupakan akibat sosialisasi atau interaksi remaja dengan lingkungannya, hal ini 
dapat di lihat dari hasil penelitiannya yang menunjukkan bahwa interaksi sosial remaja berisisko menyalahgunakan NAPZA pada remaja SMP dan SMA berisiko tinggi menyalahgunakan NAPZA.

5. Peran tokoh masyarakat di sekitar Sekolah SMA N 3 Sorong terhadap kebiasaan konsumsi alkohol belum ada hingga sekarang tidak ada program ataupun kegiatan yang dilakukan untuk mencegah ataupun melawan penyalahgunaan alkohol di masyarakat, terutama pada siswa sekolah yang berada di llingkungannya. Padahal hampir semua informan mengetahui bahwa kebiasaan mengkonsusmi alkohol pada remaja sudah sangat memprihatinkan. Kurangnya peran tokoh masyarakat di sekitar lingkungan sekolah, menjadi salah satu factor yang mendukung sulitnya dihilangkan kebiasaan konsumsi alkohol pada siswa sekolah. Banyaknya pertimbangan dan kekhawatiran tokoh masyarakat setempat ketika akan mengeluarkan kebijakan tentang pengendalian tersebut. Selan telah menjadi kebiasaan masyarakat sehingga masyarakat kurang peduli dan acuh tak acuh terhadap program pencegahan atau perlawanan yang akan dilakukan juga menjadi factor yang memunculkan pertimbangan dan dilemma saat akan melakukan intervensi kepada masyarakat.

6. Kemudahan akses, Faktor ini merupakan salah satu faktor yang mempengaruhi remaja untuk mengkonsumsi minuman beralkohol karena minuman beralkohol disana sangat mudah di dapatkan dengan tersedianya warung-warung dan toko-toko yang menjual minuman beralkohol. Hasil penelitian yang di lakukan oleh Mulyati Nasrun (2009) pada anak jalanan kota Makassar, menjelaskan bahwa faktor pendukung semakin terbiasanya anak-anak jalanan mengkonsumsi minuman beralkohol juga dapat terjadi karena mereka dapat dengan mudahnya mengakses dan mendapatkan minuman beralkohol. Pada proses ini faktor pendukung dekatnya lokasi penjualan minuman beralkohol dari sekolah SMAN 3 Sorong menjadi berarti. Menurut aparat kepolisian walaupu sering diadakan razia-razia terhadap warung-warung yang menjual alkohol tetapi tidak ada efek jera yang di dapatkan. Walaupun pihak kepolisian, juga mengadakan penagkapan dan penyitaan terhadap kepemilikan minuman beralkohol. Mereka tetap menjual dengan cara sembunyisembunyi untuk mengelabui pihak kepolisian. Hal senada juga di sampaikan oleh bagian hukum Pengendalian dan Pengawasan Penjualan MInuman Beralkohol, bahwa tidak adanya kepedulian masyarakat setempat untuk melaporkan pelanggaran yang terjadi terhadap para penjual minuman beralkohol yang tidak mengantongi surat izin, sehingga secara hukum walaupun telah ada peraturan daerah yang mengatur tentang konsekuensi hukuman jika ada yang melanggar, tetapi secara tekhnis masih bisa lolos dari jangkauan pemerintah daerah sendiri.

7. Setiap Informan memiliki efek yang berbeda setelah mengkonsumsi alkohol yaitu pusing, sesak napas, muntah, sering mengantuk dan menjadi pemalas. Berdasarkan hasil wawncara mendalam hampir semua remaja merasakan hal yang sama yaitu pusing dan muntah setelah mengkonsumsi alkohol. Di pagi harinya mereka merasa sering mengantukdan menjadi malas untuk bangun, saat merka mengkonsumsi di sekitar area sekolah, mereka langsung tertiudr ataupun mereka merasa ngantuk di kelas, dan tidak konsentrasi terhadap pelajaran

Menurut aparat kepolisian banyak tindakan kriminal yang terjadi dan diantaranya dilakukan oleh remaja dibawah pengaruh minuman beralkohol, diantaranya yaitu perkelahian, penganiayaan, pencurian dan tidak sedikit tindakan asusila. Hasil penelitian lain dari Fitria (2012) subjek melakukan perilaku criminal saat mabuk minuma beralkohol. Hal ini dapat dilihat bahwa subjek minum minuman beralkohol pada saat ingin melakukan tindakan criminal (memalak, berkelahi atau memukul seseorang) agar lebih berani, percaya diri dan tidak begitu sadar akan kejadian yang ia lakukan.

\section{Pembahasan}

Melihat fenomena yang terjadi pada remaja saat ini, terutama remaja usia sekolah, masyarakat sendiri yang mengetahui adanya praktek menjual minuman beralkohol, seakan tidak peduli, bahkan enggan melaporkan kepada aparat kepolisian ketika mengetahui temapt dan waku para penjual melkukan transaksi penjualan terhadap beberapa remaja sekolah. Sebagaiman tindakan remaja sekolah di sana yang mengkonsumsi minuman keras, kebanyakan sebagai wujud rasa solidaritas sesame teman. Sehingga tindakan mengkonsumsi minuman beralkohol tersebut telah memiliki otoritas yang memaksa seseorang untukmelaksanankannya. Dengan bertolak dari pandangan Weber, ia menerangkan bahwa tindakan manusia menjadi suatu hubungan social bila manusia memberikan arti atau makna tertentu terhadap tindakannya itu, dan manusia lain memahami pula tinakannya itu sebagai sesuatu yang penuh arti.

Di daerah Timur Indonesai sendiri, terutama di Papua. Budaya kesopanan para leluhur timur masyarakat setempat menggunakan minuman beralkohol sebagai simbol rasa hormat kepada tamu yang datang berkunjung ke tanah papua, hal ini tentu saja di adopsi dari budaya barat. Akan tetapi, minuman yang di suguhkan tidak sampai memabukkan. Namun seiring berjalannya waktu terjadi pergeseran makna yang sesungguhnya. Sehingga bukan lagi menjadi budaya sopan santun, tetapi berubah menjadi sesuatu yang negative bahkan menjadi candu di daerah sendiri. Sehingga kebiasaan mengkonsumsi alkohol, menjadi hal yang biasa dan di tiru oleh generasi selanjutnya. 
Sebagian masyarakat pun prihatin dengan kebiasaan tersebut, terutama masyarakat yang berada dan tinggal di lingkungan sekolah SMA N 3 Sorong. Bahwa apa yang dilakukan remaja disaat ini merupakan sebuah bentuk dari pelarian dan pelampiasan dari masalah-masalah tertentu. Pada kenyataannya kepribadian para siswa sekolah yang cenderung tidak sabaran dan memberontak menjadi factor yang melatarbelakangi mereka mengonsumsi minuman beralkhol. Sebagaimana di jelaskan di atas bahwa selain pelarian dari masalah, pengaruh lingkungan pergaulan juga mempunyai andil yang cukup besar dalam pembentukan kepribadian seseorang. Menurut Wirawan (2011) Faktor menkonsumsi alkohol sebagai berikut :

1. Sosial, didasari motif-mmotif social seperti adany pengaruh pergaulan, perubahan gaya hidup, system norma social,

2. Ekonomi, menngkatnya jumlah penggunaan minuman beralkohol di Indonesia dapat di sosialisasikan dengan factor keterjangkauan harga minuman keras local dengan daya beli atau kekuatan ekonomi masyarakat dan secara makro industry minuman kea baik itu di tingkat produksi, distribusi dan periklanan ternyata mampu menyumbang porsi yang sangat besar bagi pendapatan Negara.

3. Budaya, di Indonesia banyak di jumpai produksi local minuman keras yang merupakan warisan tradisional yaitu arak dan tuak yang banyak di konsumsi oleh masyarakat dengan alasan tradisi.

4. Lingkungan. Peranan Negara dalam menciptakan lingkungan yang bersih minuman beralkohol menjadi sangat vital. Bentuk-bentuk aturan dan regulasi tentang minumankeras, serta pelaksanaan daripada aturan dan regulasi tentang minumna keras, serta pelaksanaan daripada aturan dan regulasi tersebut secara tegas menjadi kunci utama penanganan masalah alkohol ini. Peranan provider kesehatan juga sangat penting dalam mempromosikan kesehatan.

a. Kepribadian Remaja

Dari hasil wawancara di atas menyimpulkan bahwa kepribadian pengguna alcohol juga turut berperan pada remaja. Penyalahguna alkohol memiliki konsep diri dan harga diri yang rendah. Perkembangan emosi yang terhambat dengan di tandai ketidakmampuan individu mengekspresikan emosinya secara wajar, mudah cemas, pasif, agresif dan cenderung depresi. Hal ini turut mempengaruhi konsumsi alkohol pada remaja.

Dalam buku Karamoy, 2004 faktor internal yang mempengaruhi seorang remaja mengkonsumsi alkohol, yaitu faktor kepribadian anak (termasuk di dalamnya harga diri), pengaruh usia, pandangan atau keyakinan yang salah terhadap diri sendiri, religiusitas dan ego yang tidak realistis. Kepribadian informan terhadap konsumsi alkohol termasuk factor predisposisi yang mendorong kebiasaan remaja mengkonsumsi alkohol, terutama di area sekolah. Kepribadian di pengaruhi oleh faktor hereditas (pembawaan) maupun lingkungan (fisik, social, kebudayaan, spiritual) (Syamsu, 2011).

b. Peran orang tua terhadap Kebiasaan konsumsi alkohol pada remaja

Peran orang tua terhadap anaknya terutama yang menjalankan pendidikan di bangku SMA merupakan bentuk interaksi antara orang tua yang berusaha memberdayakan prinsip-prinsip kehidupan kepada anak, sehingga anak memahami dan melaksanankan nya selama mengadakan pengasuhan yang berarti orang tua menddik, membimbing dan melindungi anak (Gunarso, 2005). Berdasarkan hasil penelitian hampir seluruh informan berperan cukup dan kurang. Beberapa informan (bapak) memiliki pengalaman mengkonsumsi alkohol walaupun sekarang telah berhenti mengkonsumsi alkohol, karena melihat orang tua (bapak) mereka mengkonsumsi alkohol untuk itu anak mereka mengadopsi kebiasaan orang tua mereka dan pada akhirnya mencoba alkohol.

Hasil penelitian Amirul (2015) mengatakan bahwa pengaruh paling kuat yang menyebabkan seorang remaja sekolah mengkonsumsi minuman beralkohol adalah figure contoh dari orang tuanya. Ketidak mampuan orang tua dalam mengontrol emosi membuat anak menjdi temperamental, sulit diatur, cenderung berbuat criminal, dan berpeluang mengkonsumsi alkohol untuk menghilangkan beban yang di hadapi dari orang tuanya. Akaibatnya orang tua demikian tidak bisa menjadi model atau peran yang baik bagi anak-anaknya dalam mengontrol anak serta mengasuh buah hatinya.

c. Peran Lingkungan Sekolah Terhadap kebiasaan Konsumsi Alkohol pada remaja Siswa

Teori belajar selalu di hubungkan dengan stimulus-respon dan teori tingkah laku yang menjelaskan respons makhluk hidup di hubungkan dengan stimulus yang di dapat dalam lingkungannya. Menurut Albert Bandura ahli psikologi kanada, di sebut juga modeling yaitu tekhnikborang yang ditiru tingkah lakunya, Albert Bandura menyatakan manusia secara semula jadi belajar melalui proses peniruan/pengamatan yaitu dengan cara melihat orang lain.

Ini sesuai dengan penelitian oleh Raymond dan Judith (2004:41) menyebutkan bahwa motivasi belajar adalah sebuah ciri pribadi, orang tua, dan guru (lingkungan sekolah) membantu dan mengembangkannya sebagaimana mereka juga mungkin memelihara keteguhan hati atau kepercayaan diri dalam diri seorang anak. Untuk itu motivasi belajar yang di sediakan oleh lingkungan sekolah sangat berperan penting untuk menanggulangi kebiasaan konsumsi alkohol pada anak. Hubungan kerja sama dan komunikasi yang baik seorang guru dan orang tua secara berkesinambungan, dapat menjadi motivasi 
anak untuk lebih semangat belajar dan memfokuskan diri untuk belajar, agar terhindar dari kenakalan remaja seperti mengkonsumsi alkohol.

d. Peran teman sebaya terhadap kebiasaan konsumsi alcohol

Kelompok sebaya, berpengaruh kuat terhadap terjadinya penyalahgunaan NAPZA. Individu akan merasa cemas jika di tolak oleh lingkungan, sehingga berusaha mencari persetujuan kelompok. Konflik anatar orang tua dan remaja adalah konflik loyalitas terhadap teman sebaya. Ramaja sangat peka terhadap nilai-nilai kelompok sebaya dalam penampilan, perilaku, dan sikap, bahkan kebiasaan. Tidak semua remaja memiliki kemauan ego yang teguh dan berpisah dari nilai-nilai.aturan/norma kelompok sebaya. Dalam lingkungan sekolah terdapat interaksi teman sebaya dimana proses interaksi teman sebaya akan saling mempengaruhi, karena adanya penyesuaian diri pada norma/aturan/nilai-nilai yang sudah di tetapkan dalam interaksi teman sebaya.

Menurut Jaji (2009) resiko penyalahgunaan NAPZA pada umunya pertama kali di kenalkan oleh teman. Perilaku menyalahgunakan NAPZA pada remaja juga merupakan akibat sosialisasi atau interaksi remaja dengan lingkungannya, hal ini dapat di lihat dari hasil penelitiannya yang menunjukkan bahwa interaksi social remaja berisisko menyalahgunakan NAPZA pada remaja SMP dan SMA berisiko tinggi menyalahgunakan NAPZA yaitu sebsar $71,1 \%$ artinya remaja yang memiliki sosialisasi tinggi berisiko tinggi pada penyalahgunaan NAPZA.

Hal ini sesuai dengan hasil penelitian Hawari (dalam Jaji, 2001) bahwa pengaruh teman sebaya memiliki 51,1 \%. Pada umumnya remaja menggunakan NAPZA di kenalkan oleh teman dan mengkonsumsinya bersama-sama antar 3-5 orang. Karena, remaja dalam kehidupan sosial sangat tertarik pada kelompok sebayanya sehingga tidak jarang orang tua di nomor duakan sedangkan kelompoknya di nomor satukan. Hal tersebut terjadi karena dalam kelompok itu remaja dapat memenuhi kebutuhannhya, seperti kebutuhan di mengerti, kebutuhan di anggap,di perhatikan, dan mencari pengalaman baru, dan sebagainya.

e. Peran Tokoh Masyarakat terhadap KOnsumsi Alkohol Pada Remaja Siswa

Di dalam Kehidupan bermasyarakat, tokoh masyarakat menduduki posisi yang penting. Oleh karena itu ia di anggap orang serba tahu dan mempunyai pengaruh yang besar terhadap masyarakat. Sehingga segala tindak-tanduknya merupakan pola aturan yang patut di teladani oleh masyarakat. Tokoh masyarakat adalah seseorang yang berpengaruh dan di tokohkan di lingkungannya. Penokohan tersebut karena pengaruh posisi, kedudukan, kemampuan dan kepiawaiannya serta segala tindakan dan ucapannya akan diikuti oleh masyarakat sekitarnya (BKKBN, 2008). Kurangnya peran tokoh masyarakat di sekitar lingkungan sekolah, menjadi salah satu factor yang mendukung sulitnya di hilangkan kebiasaan konsumsi alkohol pada siswa sekolah. Banyaknya pertimbangan dan kekhawatiran tokoh masyarakat setempat ketika akan mengeluarkan kebijakan tentang pengendalian tersebut. Selan telah menjadi kebiasaan masyarakat sehingga masyarakat kurang peduli dan acuh tak acuh terhadap program pencegahan atau perlawanan yang akan di lakukan juga menjadi factor yang memunculkan pertimbangan dan dilemma saat akan melakukan intervensi kepada masyarakat.

Hal tersebut di benarkan oleh penelitian (Lumban Gaol, 2013) yang menunjukkan bahwa sebagian besar masyarakat menentang keras kebijakan pemerintah untuk memberantas tuak. Menurut mereka, tuak merupakan minuman khas yang mencirikan tradisi yang sangat melekat pada masyarakat Batak Toba dan tuak telah di wariskan secara turun temurun sebagai warisan dari nenek moyang sebagai minuman pelepas keletihan. Demikian pula di papua cap tikus menjadi budaya masyarakat yang melekat dan menjadi cirri khas dari masyarakat Papua yang diwariskan secara turun temurun, namun budaya tersebut dimasa lalu merupakan budaya positif dengan tujuan mempeerta tali persaudaraan, menjadi salah satu ajang kehormatan dalam menyambut tamu. Namun, seiring berjalannya waktu terjadi pergesaran makna hingga jauh dari makna dan nilai fisiologis sebenarnya. Pada akhirnya kebiasaan minuman alcohol menjadi sebuah perilaku negative dan tidak terkontrol.

f. Kemudahan akses Terhadap kebiasaan konsumsi alkohol pada Remaja

Faktor ini merupakan salah satu faktor yang mempengaruhi remaja untuk mengkonsumsi minuman beralkohol karena minuman beralkohol disana sangat mudah di dapatkan dengan tersedianya warungwarung dan toko-toko yang menjual minuman beralkohol. Hasil penelitian yang di lakukan oleh Mulyati Nasrun (2009) pada anak jalanan kota Makassar, menjelaskan bahwa faktor pendukung semakin terbiasanya anak-anak jalanan mengkonsumsi minuman beralkohol juga dapat terjadi karena mereka dapat dengan mudahnya mengakses dan mendapatkan minuman beralkohol. Banyaknya warung-warung yang menjual alkohol secara bebas di karenakan banyaknya masyarakat yang memang ingin membeli alkohol dan juga keuntungan yang besar yang di dapatkan oleh para penjual. Menurut aparat kepolisian walaupu sering di adakan razia-razia terhadap warung-warung yangmenjual alkohol tetapi tidak ada efek jera yang didapatkan. Walaupun pihak kepolisian, juga mengadakan penagkapan dan penyitaan terhadap kepemilikan minuman beralkohol. Mereka tetap menjual dengan cara sembunyi-sembunyi untuk mengelabui pihak kepolisian. 
Hal senada juga di sampaikan oleh bagian hukum Pengendalian dan Pengawasan Penjualan MInuman Beralkohol, bahwa tidak adanya kepedulian masyarakat setempat untuk melaporkan pelanggaran yang terjadi terhadap para penjual minuman beralkohol yang tidak mengantongi surat izin, sehingga secara hukum walaupun telah ada peraturan daerah yang mengatur tentang konsekuensi hukuman jika ada yang melanggar, tetapi secara tekhnis masih bisa lolos dari jangkauan pemerintah daerah sendiri.

g. Dampak Konsumsi Alkohol Pada Remaja

Pada dasarnya terdapat dua jenis dampak pada pecandu alkohol, yaitu efek jangka panjang dan efek jangka pendek. Efek jangka pendek konsumsi alkohol lebih kurang satu botol besar menjadikan seseorang itu kurang daya koordinasi seperti tidak dapat berjalan dengan benar dan tidak dapat membuka pintu. Dalam jangka waktu yang singkat ini juga menyebabkan hangover. Hangover lazimnya di sebaban oleh keracunan alkohol, bahan lain dalam alkohol adalah sakit kepala, muntah, diare, gangguan pergerakan usus dan menggetar selama 8-12 jam kemudian (Nurwijaya dan Ikawati, 2009). Minuman beralkohol sama halnya dengan Narkoba yang menpunyai dampak terhadap system saraf manusia yang menimbulkan berbagai perasaan seperti meningkatkan gairah, semangat, dan keberanian, sebagian lagi menimbulkan perasaan mengantuk sedangkan yang lain bisa menyebabkan resa tenang dan nikmat sehingga bisa melupakan kesulitan.

Hal ini sesuai dengan wawancara dengan informan yang mengaku merasakan rasa pusing dan kantuk setelah mengkonsumsi alkohol. Sifat narkoba dan alkohol itu antara lain menimbulkan ketergantungan dan kecandun pada emaiaknya. Maka seiring ia memakai narkoba dan minum minuman berlakohol, makin besar ketergantungannya sehingga pada suatu saat tidak bisa melepas diri lagi. Pada tahap ini remaj ayang bersangkutan bisa berperilaku criminal atau menjasi pekerha seks untuk sekedar memperoleh uang pembeli alkohol (S.W. Sarwono, 2012).

Menurut aparat kepolisian banyak tindakan criminal yang terjadi dan diantaranya di lakukan oleh remaja di bawah pengaruh minuman beralkohol, diantaranya yaitu perkelahian, penganiayaan, pencurian dan tidak sedikit tindakan asusila. Hasil penelitian lain dari Fitria (2012) subjek melakukan perilaku kriminal saat mabuk minuman beralkohol. Hal ini dapat di lihat bahwa subjek minum minuman beralkohol pada saat ingin melakukan tindakan kriminal (memalak, berkelahi atau memukul seseorang) agar lebih berani, percaya diri dan tidak begitu sadar akan kejadian yang ia lakukan

\section{Kesimpulan}

Hasil Penelitian ini menunjukkan bahwa, kebiasaan mengkonsumsi alkohol pada remaja siswa SMA N 3 Sorong Papua, dan faktor-faktor yang membentuk kebiasaan tersebut telah di ketahui alasan-alasan dan penyebab kebiasaan konsumsi alkohol para remaja di sekolah, bagaimana kepribadian remaja di sekolah terhadap kebiasan konsumsi alkohol, bagaimana dampak mengkonsumsi alkohol, bagaimana keluarga, lingkungan sekolah, teman sebaya, tokoh masyarakat setempat, pemerintah daerah, dan ketersediaan akses terhadap kebiasaan mengkonsumsi alkohol pada remaja siswa di sekolah. Semua faktor saling berhubungan dan saling terikat satu sama lain.

\section{Saran}

1. Bagi remaja

Hasil penelitian diharapkan dapat menambah pengetahuan mengenai bahaya dampak kebiasaan mengkonsumsi alkohol sejak dini.

2. Bagi Tenaga kesehatan

Hasil penelitian ini diharapkan dapat menjadi masukan bagi petugas kesehatan dalam melaksanakan upaya pencegahan dan memberikan sosialisasi kepada siswa-siswa agar tidak mengkonsumsi alkohol.

3. Bagi masyarakat

Penelitian ini menjadi pengalaman berharga dan menambah pengetahuan bagi masyarakat serta dapat mengetahui tentang dampak kebiasaan mengkonsumsi alkohol yang dapat membahayakan kesehatan.

\section{Referensi}

Asyhar Sadikin. Jurnal Psikoborneo Volume 4 Nomor 4 Tahun 2016. Konformitas Pada Perilaku MinumMinuman Keras (Pengasih) Pada Remaja Suku Dayak Berusu Di Desa Seludau Kabupaten Tana Tidung. Program Studi Psikologi. Fakultas Ilmu Sosial dan Ilmu Politik. Universitas Mulawarman : Samarinda.

Fitria, T. 92012). Alcohol Expectancies Pada Mahasiswa Papua Yang Mengkonsumsi Alkohol. University of Muhammadiyah Malang 
Gunarso, S.D (2005). Psikologis Praktis Anak, Remaja dan Keluarga. Jakarta : BPK Gunung Mulia

Hapsari, K. M (2007). Fenomena Munculnya Alkoholisme di Kalangan Mahasiswa

Hernilawati. Cetakan I 2013. Konsep dan Proses Keperawatan Keluarga. Penerbit Pustaka As Salam : Takalar. Sulawesi Selatan.

Issakh, R.A., Ottay R \& Rombot, D. V (2016). Gambaran Perilaku Remaja Terhadap Kebiasaan Mengkonsumsi Minuman Beralkohol di Desa Sapa Kecamatan Tenga Kabupaten Minahasa Selatan Tahun 2012. Jurnal e-Biomedik, 4 (1)

Karamoy, S (20040. Ceghh sejak Dini. Rotary Internaional D-3400 RI Drug Abuse Commite. SEMARANG : FAKULTAS PSIKOLOGI UNIKA

Khosuma Edward. Jurnal e-Biomedik (eBM) Volume I Nomor I Tahun 2013. Gambaran Pengetahuan Remaja Mengenai Bahaya Alkohol Dengan Stroke. Bagian Neurologi Fakultas Kedokteran. Universitas Sam Ratulangi : Manado.

Lalongke, R, M dan Edison, A, T. 2014. Komunikasi Terapeutik, Pendekatan Prkatis Praktisi Kesehatan. Penerbit Graha Ilmu : Yogyakarta.

Lincoln, Y. S \& Guba, E. G (1985). Naturalistic Inquiry (Vol.75) : Sage

Lumban Gaol, N. H. D (2013). Dilema Pemberantasan Minuman Keras Terhadap Pelestarian Budaya Masyarakat Batak Toba ( Studi Kasus di Desa 145 Ria-ria Kecamatan Poliung Kabupaten Humbang Hasundutan). Jurnal Citizenship hal 101-121.

Majority. Jurnal Volume 4 Nomor 8 Tahun 2015. Konsumsi Alkohol dan Pengaruhnya Terhadap Kesehatan. Fakultas Kedokteran Universitas Lampung : Bandar Lampung.

Mansur, H dan Budiarti, T. 2014. Psikologi Ibu dan Anak untuk Kebidanan. Edisi 2. Penerbit Salemba Medika : Jakarta.

Maulana, H. D. (2007). Promosi Kesehatan. Jakarta : EGC

Mulyati. (2009). Perilaku Anak Jalanan Terhadap Minuman Beralkohol

Notoatmojo, S. (2014). Ilu Perilaku Kesehatan. Jakarta : Rineka Cipta, 27

Nurwijya, H, \& Ikawati, Z. (2009). Bahaya Alkohol dan cara mencegah kecanduannya : Elex Media Komputindo

Paratama Dimas, N, V. Jurnal Penelitian Tahun 2013. Perilaku Remaja Pengguna Minuman Keras Di Desa Jatigono Kecamatan Kunir Kabupaten Lumajang. Departemen Promosi Kesehatan dan Ilmu Perilaku. Universitas Airlangga : Surabaya.

Prasetyo, H. Cetakan II 2013. Sosiologi Masyarakat Jilid 2. Penerbit Mandiri Pratama : Jakarta.

Purwoastuti E, dan Walyani, S,E. 2015. Perilaku \& Softskills Kesehatan. Panduan Untuk Tenaga Kesehatan (Perawat dan Bidan). Penerbit Pustaka Baru Pres : Yogyakarta.

Putra E. (2013). Bentengi Remaja dari Bahaya Miras dan Alkohol

Rifa'i, M dan Rahmat. 2016. PAI Interdisipliner (Layananan Khusus CIBI, Kenakalan Remaja, Integrasi IMTAQ \& IPTEK, Pendidikan Anti Kekerasan dan Kurikulum Berbasis Karakter). Penerbit Deepublish : Yogyakarta.

Sarosa, S. (2012). Penelitian Kualitatif dasar-dasar. Jakarta : PT. Indeks 
Sarwono, W, S. 2015. Psikologi Remaja. Edisi Revisi. Penerbit Raja Grafindo Persada : Jakarta.

Siswendi, A. Jurnal FISIP Vol. I Tahun 2014. Perilaku Meminum-Minuman Keras Di Kalangan Remaja Di Kelurahan Sungai Salak Kecamatan Tempuling Kabupaten Indragiri Hilir. Program Studi Sosiologi FISIP. Universitas Riau : Pekanbaru.

Susanto, H. Edisi I, Cetakan I, 2014. Communication Skills, Sukses Komunikasi, Presentasi dan Berkarier. Penerbit Deepublish : Yogyakarta.

Suseno A, Dwi. Jurnal Kesehatan Tahun 2014. Perilaku Mengkonsumsi Minuman Keras Di Kalangan Remaja Awal Di Desa Kunden Kecamatan Wirosari. Fakultas Kesehatan Masyarakat. Universitas Dian Nuswantoro : Semarang.

Sutayasa, P. T. Y \& Wijaya (2006). Resiliensi dan Sikap Terhadap Penyalahgunaan Zat (Studi Pada Remaja). Jurnal Psikologi Vol, 4 92), 102

Utina, S. S (2012). Alkohol dan Pengaruhnya Terhadap Kesehatan Mental. Jurnal Health and Sport, 5 (2)

Waluyo D> P. S. N (2014). Gambaran Perilaku Konsumsi Alkohol Pada Mahasiswa

Wetipo, J., Ranteallo, I. C., \& Tamim, I. H. (2015). Penyimpanagan Sosial Munitas Mahasiswa Papua di Denpasar ( Studi Kasus Konsumsi Minuman Beralkohol ). JURNAL ILMIAH SOSIAOLOGI (SOROT), $1(09)$

Wirawan, S. S (2011). Psikologi Remaja Edisi 12. Jakarta : PT. Raja Grafindo Persada. 